\title{
FLORISTIC COMPOSITION, ENVIRONMENTAL VARIATION AND SPECIES DISTRIBUTION PATTERNS IN BURNED GRASSLAND IN SOUTHERN BRAZIL
}

\author{
OVERBECK, G. E. ${ }^{1}$, MÜLLER, S. C. ${ }^{2}$, \\ PILLAR, V. D. ${ }^{2}$ and PFADENHAUER, J. ${ }^{1}$ \\ ${ }^{1}$ Vegetation Ecology, Technische Universität München, Am Hochanger, 6, 85350 Freising-Weihenstephan, Germany \\ ${ }^{2}$ Laboratório de Ecologia Quantitativa, Departamento de Ecologia, Universidade Federal do Rio Grande do Sul, \\ Avenida Bento Gonçalves, 9500, CEP 91540-000, Porto Alegre, RS, Brazil \\ Correspondence to: Gerhard Ernst Overbeck, Vegetation Ecology, Technische Universität München, \\ Am Hochanger 6, 85350 Freising-Weihenstephan, Germany, e-mail: gerhard_overbeck@yahoo.com \\ Received February 11, 2005 - Accepted May 19, 2005 - Distributed November 1, 2006
}

(With 2 figures)

\begin{abstract}
In regularly burned grassland on Morro Santana, Porto Alegre, RS, Brazil, we investigated differences in the floristic composition and their relation to soil properties, aspect and distance from the forest border. In 48 plots of $0.75 \mathrm{~m}^{2}$, we identified a total of 201 species from a local species pool of approximately 450 to 500 species. Most species occurred in low frequencies, showing clumpy distribution patterns in the studied area. Multivariate analysis showed that plots close to the forest edge clearly differed from plots in the open grassland concerning composition and structure. Plots exposed to the north differed from plots on the top of the hill both in the composition of species as well as in soil variables, mainly due to shallower soil in the former. No strong relation between soil properties and variation in vegetation composition could be detected at a finer scale. The studied grassland, as all grassland vegetation in southern Brazil, is very rich in species compared to other grassland formations worldwide. However, this high biodiversity and conservational value of Campos vegetation in general has so far not been recognized properly. Disturbance is essential to maintain this open vegetation type and its species richness. Fire should be considered as a management option in the absence of grazing.
\end{abstract}

Keywords: diversity, fire, grassland, southern Brazil, species distribution patterns.

\section{RESUMO}

\section{Composição florística, variação ambiental e distribução das espécies em um campo queimado no sul do Brasil}

Em um campo regularmente queimado no Morro Santana, Porto Alegre, RS, Brasil, foram investigadas diferenças na composição florística e suas relações com as propriedades do solo, a distância da borda florestal e a exposição do relevo. Em 48 parcelas de $0,75 \mathrm{~m}^{2}$, foram amostradas 201 espécies identificadas, de um total estimado para o local de aproximadamente 450 a 500 espécies. A maioria das espécies apresentou baixas freqüências e uma distribuição aglomerada na área de estudo. A análise multivariada dos dados indicou que as parcelas adjacentes à borda florestal claramente diferem florística e estruturalmente das parcelas do campo. As parcelas com exposição norte diferiram das do topo do morro, tanto pela composição florística quanto pelas variáveis do solo, principalmente em relação à menor profundidade do solo no norte. Nenhuma relação forte foi detectada entre as propriedades do solo e a variação na composição da comunidade em escala mais fina. A área estudada, assim como a vegetação campestre no sul do Brasil em geral, apresenta-se muito rica em espécies, se comparada a outras formações de campo ou savana no mundo. Apesar disso, a alta biodiversidade e o valor de conservação da vegetação campestre não têm sido reconhecidos. Na ausência do pastejo, o fogo é um imporante fator de manejo para a conservação da 
vegetação campestre, uma vez que o distúrbio parece ser necessário para manter esse tipo de vegetação aberta, com alta riqueza em espécies.

Palavras-chave: Brasil meridional, campos, distribuição de espécies, diversidade, fogo.

\section{INTRODUCTION}

Grassland vegetation is typical for southern Brazil, despite climatic and edaphic conditions favorable for forest development (Rambo, 1956; Pillar, 2003). In the region, grasslands were predominant under cooler and drier glacial and warmer and drier postglacial climates and have undergone forest expansion only since approximately 4000 years BP, when the climate was moister and cooler (e.g. Klein, 1975; Behling et al., 2004). Fire has been present since the early Holocene (Behling et al., 2004) and probably occurred even before human occupation (see e.g. Furley, 1999 for Cerrado); thus, together with grazing by native or domestic animals, fire has stabilized grasslands until the present time. Since the introduction of cattle by European settlers, grazing has been the predominant land use and fire has been used for pasture management (Pillar \& Quadros, 1997). Brazilian humid subtropical grasslands have received relatively little attention both by science and conservation policies (MMA, 2000). Quantitative data on species composition and distribution patterns in relation to environmental variables is scarce. Various studies have characterized the floristic composition (e.g. Buselato \& Bueno, 1981; Aguiar et al., 1986; Boldrini \& Miotto, 1987), while only few consider relations between vegetation and abiotic or management factors (Girardi-Deiro et al., 1992; Pillar et al., 1992; Boldrini \& Eggers, 1996; Boldrini et al., 1998). This is alarming as grasslands composed of native species are rapidly disappearing due to "improvement" with exotic forage species and expansion of crops or tree plantations (Nabinger et al., 2000; MMA, 2000; Pillar, 2003; Bilenca \& Miñarro, 2004).

The granitic hills in the surroundings of Porto Alegre contain remnants of natural vegetation within the urban area. Unlike the largest part of grasslands in southern Brazil, the grasslands in this region, whose floristic richness was pointed out by Rambo (1954), are mostly not being used for grazing and are under no formal land use.
Often, grassland can be found in a heterogeneous mosaic with small forest patches and shrubland. Due to the accumulation of senescent biomass, the grasslands are often burnt and this is caused by the local population. Moreover, there are strong anthropogenic influences, which are mainly the expansion of irregular settlements (Adelmann \& Zellhuber, 2004). Without detailed studies of the present state of the vegetation, it is impossible to assess value and endangerment of the vegetation. In this paper, we report findings on the floristic composition of a grassland area on Morro Santana, Porto Alegre, RS, exploring relationships between species distribution and abiotic site conditions, and use this to discuss biodiversity and the conservational value of South Brazilian Campos vegetation in general. The role of fire in grassland dynamics will be dealt with briefly, however as it is not the main focus of this study, it will be addressed in detail elsewhere (Overbeck et al., 2005).

\section{MATERIAL AND METHODS}

\section{Study area}

The study took place on Morro Santana $\left(30^{\circ}\right.$ $03^{\prime} \mathrm{S}, 51^{\circ} 07^{\prime} \mathrm{W}$, max. alt. $311 \mathrm{~m}$ a.s.l.). The hill is covered by forests (Atlantic forest) predominantly on the southern slopes and by a mosaic of forest and grassland on the top and with grasslands dominating on the northern slopes (Aguiar et al., 1986). Due to ongoing forest expansion processes, isolated patches of woody species can be found throughout the grassland (Müller \& Forneck, 2004). Climate in the region is Köppen's Cfa, with a mean annual temperature from 18 to $20{ }^{\circ} \mathrm{C}$ and mean precipitation of approx. $1400 \mathrm{~mm} \mathrm{yr}^{-1}$, without a dry season (Nimer, 1990). The predominant soil type can be classified as a typical dystrophic redyellow argisol (Streck et al., 2002). The grassland areas are ungrazed and are subject to frequent (average fire interval: 3 years - today mostly anthropogenic) burning affecting differently sized patches of grassland every year. Fire history at the 
study site is poorly known: palaeoecological data (Behling et al., in press) indicate the occurrence of fire during the past 1200 years, but no data from further back exist.

\section{Methods}

\section{Vegetation sampling}

In the forest-grassland ecotone, six pairs of transects from the forest edge into the grassland were installed at sites with different aspects (top and northern slope). Four of the transects were subjected to experimental burning at the end of October, 2002. Transects consisted of seven $4.5 \mathrm{~m}$ by $4.5 \mathrm{~m}$ plots used in a study on woody components in the grassland. The grassland composition presented in this work was sampled in three contiguous plots of $0.5 \mathrm{~m}$ by $0.5 \mathrm{~m}$ marked permanently in the center of plots $1,3,5$ and 7 of these transects, 1 was closest and 7 farthest from the forest border. Species composition and cover of soil, litter, moss and rocks were recorded in January and February, 2003, i.e. two to three months after the burning in some of the transects, using the Londo (1976) decimal scale, i.e. 10\% cover steps. Cover data of the three adjacent $0.25 \mathrm{~m}^{2}$ plots were pooled into plots of 1.5 by $0.5 \mathrm{~m}\left(0.75 \mathrm{~m}^{2}\right)$ for all analyses by taking the average value for each species or structural attribute.

\section{Soil sampling}

For each of the 4.5 by $4.5 \mathrm{~m}$ plots, a mixed soil sample of the first ten centimeters of the soil profile was taken at five points randomly distributed in the plot and analyzed by the Laboratório de Análises de Solo, UFRGS, Porto Alegre, determining the following parameters (following the methodology described in Tedesco et al., 1995; units see Table 2): $\mathrm{pH}$ value, share of the clay fraction (clay), content of organic matter (org. mat), available phosphorus (P), available potassium $(\mathrm{K})$, exchangeable aluminium $(\mathrm{Al})$, calcium $(\mathrm{Ca})$ and magnesium $(\mathrm{Mg})$, potential cation exchange capacity (CECpot), potential Al (AlSpot) and base (BsSpot) saturation and potential acidity $(\mathrm{Al}+\mathrm{H})$. Depth of soil available for penetration by roots was measured using a Pürkhauer drill, calculating the mean value from two drillings per plot. It was not possible to drill deeper than one meter.

\section{Data analysis}

According to Boldrini \& Miotto (1987), we calculated the mean cover over all plots $\left(\mathrm{MC}_{\mathrm{s}}\right)$, relative frequency $\left(\mathrm{RF}_{\mathrm{s}}\right)$, relative cover $\left(\mathrm{RC}_{\mathrm{s}}=\mathrm{MC}_{\mathrm{s}}, / \sum \mathrm{MC}_{\mathrm{n}}\right)$ and importance value $\left(\mathrm{IV}_{\mathrm{s}}=\mathrm{RC}_{\mathrm{s}}+\mathrm{RF}_{\mathrm{s}}\right)$ for all species. To investigate species distribution patterns, we calculated the Jaccard-coefficient for all plots taken pairwise (Krebs, 1998), thus obtaining percentage values for the relative similarity of composition between two plots. Coefficient values were categorized according to distance between plots, i.e., 1) within the same transect, 2) between transects in the same transect pair, 3) between adjacent transect pairs and 4) between distant transect pairs and compared them by analysis of variance with randomization testing (Pillar, 2004a).

Compositional patterns were analysed using species cover and species grouped according to biological forms. For the latter, individual species cover values were summed for each plot according to the following groups: Succulents, grasses, Cyperaceae, bulbous geophytic species (e.g. from Iridaceae, Liliaceae, Amarylidaceae), herbs (excluding Fabaceae), herbs from the Fabaceae, shrubs, lianas, and trees and joined by the cover of structural variables (litter, open soil, rocks, moss). Species present in less than $10 \%$ of the plots involved in the analysis were not considered in the analyses of species data. Ordination by Principal Coordinates Analysis (PCoA) was applied to species and biological form data sets using chord distance as a resemblance measure (Podani, 2000). This distance implies normalization of data within sampling units and thus disregards differences in the total cover between plots, which may result from fire history. Ordination axes were tested by bootstrap resampling (Pillar, 1999).

We tested the influence of the situation of the plots along the gradient border-grassland of the location of transects on Morro Santana (aspect) and of the interaction of these factors on species composition by multivariate analysis of variance with randomization testing (Pillar \& Orlóci, 1996; Pillar, 2004a). Furthermore, plots grouped according to their position along transects were compared for each biological form by the same technique in its univariate form. Correspondingly, the soil data set was analysed separately for each variable, testing for the factor position of plots 
along the transect and aspect. As soil sampling had been conducted almost one year after the fire experiments, differences in fire history were not considered (Rheinheimer et al., 2003). Furthermore, plots were ordinated by PCoA using all variables (based on Euclidean distance after centering and normalization within variables, Podani, 2000).

The congruency between environmental and vegetation data was calculated to find out which environmental variables were the most relevant to explain vegetation composition patterns, according to the stepwise procedure presented by Pillar \& Orlóci (1993). The algorithm involves the computation of a matrix correlation between plot data dissimilarities based on species composition and dissimilarities of the same plots based on the environmental variables in a stepwise process, giving both the correlation coefficient for those variables that maximize correlation and total congruence for the set of all variables, similar to a Mantel test.

We used the SYNCSA software (Pillar, 2004b) for ordination analyses and for ranking environmental variables by congruence and the MULTIV software (Pillar, 2004a) to perform bootstrap resampling in ordination and for randomization testing. Randomization tests involved 1,000 random permutations and bootstrap resampling 1,000 bootstrap samples. A threshold of $\alpha=0.05$ was adopted to reject the null hypothesis in randomization tests.

\section{RESULTS}

\section{Overall species composition and vegetation structure}

In our survey, a total of 232 (morpho-)species were recorded. Of these, eight could not be identified at all, seventeen only to the family and six only to the genus level, resulting in a total of 201 identified species belonging to 136 genera and 49 families (see Appendix for list). Considering only totally identified species, Poaceae (21 genera; 40 species) and Asteraceae $(21 ; 42)$ had the highest number of genera and families, followed by Leguminosae (14; 16), Rubiaceae $(5 ; 12)$ and Cyperaceae $(5 ; 9) .28$ families were represented with one species only.

Even though explanatory power of PCoA axes using species data of all plots was low (13.8\%, $11.0 \%$ and $9.0 \%$ for axes 1,2 and 3, respectively; diagram not shown), the plots close to the forestgrassland border were clearly separated from the grassland plots which did not show any grouping according to distance from the border (see Table 1). Using species groups and structural data for the

TABLE 1

Mean cover values of species groups and structural attributes for plots with different distance from the forest border on Morro Santana, Porto Alegre, RS, Brazil.

\begin{tabular}{|c|c|c|c|c|}
\hline Species groups & plot 1 (border) & grassland plot 3 & grassland plot 5 & grassland plot 7 \\
\hline tree $* *$ & 4.84 & 0.11 & 0.86 & 0.00 \\
\hline shrubs $^{\text {ns }}$ & 6.28 & 16.53 & 11.69 & 10.97 \\
\hline Lianas*** & 15.44 & 0.39 & 0.36 & 0.47 \\
\hline grasses $* * *$ & 23.39 & 55.28 & 48.61 & 46.42 \\
\hline herbs*** & 12.64 & 28.72 & 26.86 & 27.33 \\
\hline Fabaceae $^{\text {ns }}$ & 0.94 & 2.78 & 2.61 & 2.64 \\
\hline Cyperaceae** & 0.81 & 3.19 & 2.36 & 2.56 \\
\hline geophytes $^{\text {ns }}$ & 0.47 & 0.97 & 0.31 & 0.58 \\
\hline litter*** & 56.61 & 17.72 & 15.92 & 14.28 \\
\hline open soil** & 3.50 & 22.44 & 23.67 & 24.19 \\
\hline rocks ${ }^{\mathrm{ns}}$ & 0.00 & 1.67 & 6.22 & 6.06 \\
\hline mosses $^{\text {ns }}$ & 0.11 & 0.25 & 0.00 & 0.08 \\
\hline
\end{tabular}

Significant differences of the contrast between plot 1 (border plot) and plots 3, 5 and 7 (grassland plots) taken as a group are indicated for each variable (n.s.: not significant, ${ }^{*}: \mathrm{p}<0.01$, and $*^{* *}: \mathrm{p}<0.001$ ). Succulents are not included, as present in one plot only. 
ordination, this separation became much more obvious: explanation of the axes now amounted to $46.7 \%, 20.7 \%$ and $14.0 \%$, for axis 1,2 and 3, respectively, with border plots clearly separated along the first ordination axis (Fig. 1a). Due to these differences in composition and structure between border and grassland plots, we separated grassland plots (i.e. plots 3, 5, 7) and border plots (plot 1) for further analysis and description, focusing on the grassland plots in this presentation.

\section{Grassland plots: species composition and distribution}

In the grassland itself, 198 (morpho-)species were found. Of these, 170 species, belonging to 114 genera and 38 families, were identified (see Appendix 1). On average, 18.6 species (range: 4 to 33) were found for each grassland plot of $0.25 \mathrm{~m}^{2}$, and 33.9 (range: 19 to 48 ) for each pooled plot of $0.75 \mathrm{~m}^{2}$. The species area curve (Fig. 2a) indicates that stability was not reached to evaluate the species richness, as it is rising constantly in its second half.

Even in burned areas, caespitose grasses clearly dominated the studied grassland. Among the ten most dominant species, accounting for $41.4 \%$ of the total species cover, seven were grasses, and among the 30 most dominant species, already accounting for $71.2 \%$ of the total species cover, 16 were grasses (note that the total species cover is the cumulative value of single species' relative cover values, i.e. total cover of all species will exceed vegetation cover). The most dominant grass species were Elionurus muticus, Aristida flaccida, Aristida laevis, Andropogon lateralis and Leptochoryphium lanatum. All shrub species together accounted for $14.4 \%$ of the total species cover and the most dominant were Baccharis patens, B. cognata, Vernonia nudiflora, Heterothalamus psiadioides and Croton cf. nitrariaefolius. Among forb species, the rosette species Eryngium pristis and $E$. horridum showed the highest cover and importance values, followed by Vernonia flexuosa, Aspilia montevidensis, Pfaffia tuberosa, Pterocaulon rugosum and Eryngium sanguisorba. The largest part of the species had very low $\mathrm{RC}_{\mathrm{s}}$ and $\mathrm{IV}_{\mathrm{s}}$ values, with 128 species showing $\mathrm{RC}_{\mathrm{s}}$ values of only $0.25 \%$ or less, and 107 species a $\mathrm{IV}_{\mathrm{s}}$ value below 0.50 (Appendix 1). While the total cover of plants was lower in recently burned plots, dominance relations did not differ substantially when compared to unburned plots (see also below; compare Fig. 1b).

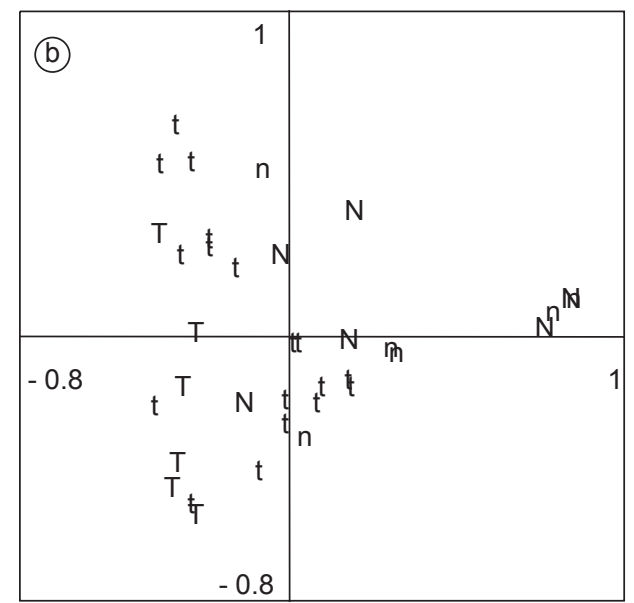

Fig. 1 - Ordination diagrams (PCoA; chord distance as resemblance measure) of grassland vegetation on Morro Santana, RS, Brazil. a) All plots $(n=48)$, based on cover of species groups and structural variables. Plots are labelled according to the distance from the forest border (1: border plots, 3, 5, 7: grassland plots with increasing distance from the forest border). Position of original descriptors (see text for details) is shown when correlation to at least one of the ordination axes was greater than 0.4. For clarity of the diagram, symbols are omitted and labels centered on the coordinate values. Explanatory power of ordination axes: 46.7, 20.7 and 14.0\% for axes 1, 2 and 3 (not shown), respectively. Axes were not stable to bootstrap sampling. b) Grassland plots $(\mathrm{n}=36)$, using species data. Plots are labelled according to aspect $(\mathrm{t}=\mathrm{top}, \mathrm{n}=$ northern slope). Capital letters indicate plots burned three months before the survey. Explanatory power of ordination axes was 15.8, 11.9 and $10.2 \%$ for axes 1, 2 and 3 (not shown), respectively. Axes were not stable to bootstrap sampling 

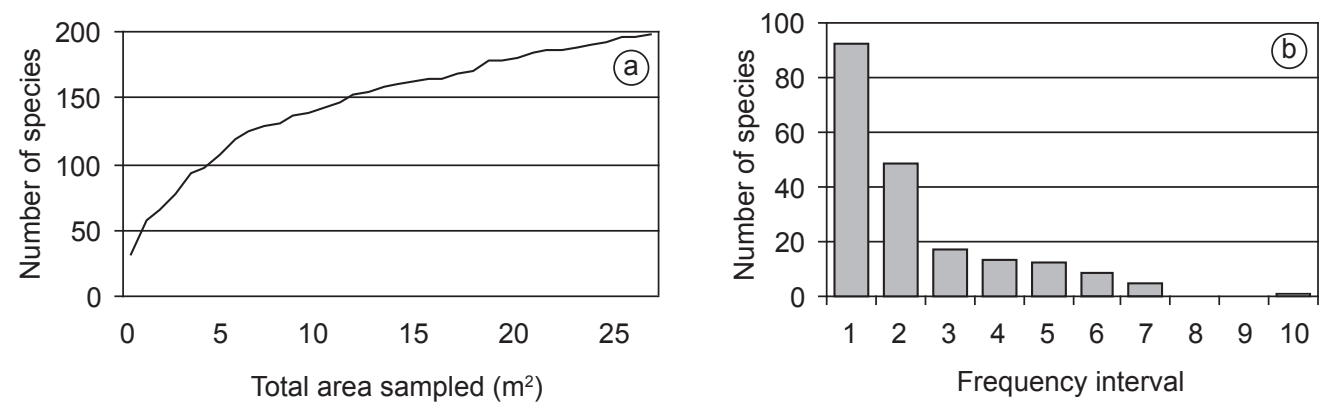

Fig. 2 - Heterogeneity of grassland vegetation, based on data from 36 grassland plots $\left(0.75 \mathrm{~m}^{2}\right)$ on Morro Santana, Porto Alegre, RS, Brazil. a) Species area curve; and b) Frequency histogram of grassland species. Species grouped into $10 \%$ frequency intervals $(1:>0 \leq 10,2:>10 \leq 20,3:>20 \leq 30,4:>30 \leq 40,5:>40 \leq 50,6:>50 \leq 60,7:>60 \leq 70,8:>70 \leq 80$, 9: $>80 \leq 90$, and $10:>90<100)$.

Species composition over the total area was very heterogeneous. Only one species Rhynchospora globularis - occurred in more than $75 \%$ of the plots and only five more (V. nudiflora, V. flexuosa, Evolvulus sericeus, P. tuberosa and E. muticus) in more than $60 \%$ of all plots. More than $50 \%$ of the species occurred in less than $10 \%$ of the plots (Fig. 2b), 59 species only in one plot. When looking at the species frequency separate from the cover values, grass species were of less relevance: out of the 30 most frequent species, only six were grasses. Some herbaceous species, especially small perennial herbs such as E. sericeus, Chaptalia runcinata, Lucilia acutifolia, Hydrocotyle exigua, Euphorbia selloi or Relbunium hirtum, showed high frequency values, similar to a number of shrub species (V. nudiflora, $C$. cf. nitrariaefolius, Porophyllum lanceolatum, B. cognata, Eupatorium ligulaefolium).

Species distribution was generally patchy and most species were not widely distributed in the study area. The comparison of joint species in any pair of plots with the help of the Jaccard-coefficient showed that plots within the same transect shared more species $(31.5 \%)$ than plots in paired transects of the same transect pair (26.4\%), plots in adjacent transect pairs $(21.6 \%)$ and plots in distant transect pairs (18.0\%; differences always significant).

When ordinating grassland plots used species data, the explanatory power of the axes was low $(15.8 \%, 11.9 \%, 10.2 \%$ for axes 1,2 and 3, resp.; Fig. 1b), however, plots on the top and on the northern side of Morro Santana were clearly separate. Apart from this, plots were mostly kept together according to geographical vicinity: plots from one transect pair were usually packed quite closely in the ordination space, albeit overlapping with other transect pairs. No relation could be detected considering the situation of grassland plots on the gradient from the forest border. Distribution of plots did not reflect the burning conducted in part of the plots three months before: burned and unburned plots were mixed throughout the ordination space.

\section{BORDER PLOTS: SPECIES COMPOSITION AND STRUCTURAL ATTRIBUTES}

Concerning the species composition in the border plots, we did not reach sampling sufficiency, especially when considering that 67 of the 125 species found occurred only in one plot each, even though - as in the grassland plots - a large proportion of herbaceous species would most likely show a very sparse distribution in the border plots as well. We therefore will only give a brief description of species groups, structural variables and the most dominant species sampled in the border plots. 34 species were found exclusively in the border plots, some of them, however, species known from the literature as grassland species, which were supposedly not found there due to patchy distribution patterns. With a mean value of $57 \%$, border plots - where generally no burning occurs due to the lack of continuous flammable biomass - showed significantly and substantially higher values for litter than grassland plots. Lianas and trees had significantly higher 
cover values, whereas the cover of herbs, grasses, Fabaceae and Cyperaceae was generally a lot and partially significantly lower, similar to values for open soil (Table 1, Fig. 1). Calea serrata, Dioscorea multiflora (lianas), Calamagrostis viridiflavescens, Oplismenus hirtellus, Panicum ovuliferum (grasses), Diodia cymosa, Peperomia pereskiaefolia (herbs), Dodonaea viscosa, Psychotria carthagenensis (shrubs), Myrsine coriacea (tree) and Rumohra adiantiformis (herbaceous fern) were frequent species found exclusively at the border. In total, seven trees, six shrubs and six liana species were found only in border plots (Appendix 2). On average, border plots were less rich in species than grassland plots: 10.4 species could be found for plots of $0.25 \mathrm{~m}^{2}$, and 21.8 species (range: 9 to 32 ) for pooled plots of $0.75 \mathrm{~m}^{2}$.

\section{EXPLANATORY VARIABLES}

Multivariate analysis of variance of the species data revealed that plots situated at the forestgrassland border (plot 1) differed significantly from plots 3, 5 and 7, thus confirming the trends shown in Fig. 1a. Plots from the northern side of the hill differed from those on the top; the interaction between the factor distance from the border and aspect was not significant.

Along the gradient from the grassland into the forest, the soil tended to become deeper closer to the edge of the forest, even though differences were not significant. $\mathrm{pH}$ values were lowest in plots closer to the forest border, albeit differing significantly between 1 and 3 and 1 and 5 only, similar to $\mathrm{Al}$ and $\mathrm{Al}+\mathrm{H}$, which showed higher values in the border plots. CECpot at the border was significantly higher than in plots 3 and 5 , but not plots 7 . None of the other factors analysed differed significantly with respect to distance to the forest border (Table 2a). Differences in soil properties between plots on the top and the northern slope of the hill were much more significant, differing for almost all parameters (Table 2b). Soils on the northern slope were shallower, had higherpH values, higher contents of $\mathrm{Mg}, \mathrm{K}, \mathrm{Ca}$ and higher CECpot and BsSpot. Clay and $\mathrm{Al}$ content and AlSpot were higher in soils on the top. Concordantly, PCoA of plots using soil data revealed a clear separation of the northern slope and top along the first axis (explanation: $64.3 \%, 12.5 \%, 8.5 \%$, for axis 1,2 , and 3 , resp.; graph not shown).

TABLE 2

Mean values of soil properties in grassland plots on Morro Santana, Porto Alegre, RS, Brazil.

\begin{tabular}{|c|c|c|c|c|c|c|c|c|c|c|c|c|}
\hline \multirow[b]{2}{*}{ soil properties } & \multicolumn{8}{|c|}{$\mathbf{A}$} & \multicolumn{4}{|c|}{ B } \\
\hline & plot 1 & & plot 3 & & plot 5 & & plot 7 & & top & & north & \\
\hline depth $(\mathrm{cm})$ & 81.1 & $\mathrm{a}$ & 75.3 & $\mathrm{a}$ & 72.1 & $\mathrm{a}$ & 66.4 & $\mathrm{a}$ & 90.7 & $\mathrm{a}$ & 39.8 & $\mathrm{~b}$ \\
\hline org. mat. (\%) & 4.6 & $\mathrm{a}$ & 4.6 & $\mathrm{a}$ & 4.5 & $\mathrm{a}$ & 4.9 & $\mathrm{a}$ & 4.7 & $\mathrm{a}$ & 4.7 & $\mathrm{a}$ \\
\hline clay $(\%)$ & 35.6 & $\mathrm{a}$ & 36.3 & $\mathrm{a}$ & 35.9 & $\mathrm{a}$ & 38.8 & $\mathrm{a}$ & 40.3 & $\mathrm{a}$ & 29.3 & $\mathrm{~b}$ \\
\hline $\mathrm{pH}$ & 4.8 & $\mathrm{a}$ & 5.1 & $\mathrm{~b}$ & 5.0 & $\mathrm{~b}$ & 5.0 & $a b$ & 4.9 & $\mathrm{a}$ & 5.2 & $\mathrm{~b}$ \\
\hline $\mathrm{Al}\left(\mathrm{cmol}_{\mathrm{C}} \mathrm{L}^{-1}\right)$ & 2.4 & $\mathrm{a}$ & 1.5 & $\mathrm{~b}$ & 1.8 & $\mathrm{~b}$ & 1.9 & $a b$ & 2.3 & $\mathrm{a}$ & 1.1 & $\mathrm{~b}$ \\
\hline $\mathrm{Ca}\left(\mathrm{cmol}_{\mathrm{C}} \mathrm{L}^{-1}\right)$ & 2.4 & $\mathrm{a}$ & 2.7 & $\mathrm{a}$ & 2.3 & $\mathrm{a}$ & 2.7 & $\mathrm{a}$ & 2.2 & $\mathrm{a}$ & 3.2 & $\mathrm{~b}$ \\
\hline $\mathrm{K}\left(\mathrm{cmol}_{\mathrm{C}} \mathrm{L}^{-1}\right)$ & 145.8 & $\mathrm{a}$ & 162.8 & $\mathrm{a}$ & 174.3 & $\mathrm{a}$ & 178.2 & $\mathrm{a}$ & 155.1 & $\mathrm{a}$ & 185.5 & $\mathrm{~b}$ \\
\hline $\mathrm{Mg}\left(\mathrm{cmol}_{\mathrm{C}} \mathrm{L}^{-1}\right)$ & 1.2 & $\mathrm{a}$ & 1.3 & $\mathrm{a}$ & 1.2 & $\mathrm{a}$ & 1.3 & $\mathrm{a}$ & 1.2 & $\mathrm{a}$ & 1.4 & $\mathrm{~b}$ \\
\hline $\mathrm{P}\left(\mathrm{cmol}_{\mathrm{C}} \mathrm{L}^{-1}\right)$ & 2.2 & $\mathrm{a}$ & 2.0 & $\mathrm{a}$ & 1.9 & $\mathrm{a}$ & 2.0 & $\mathrm{a}$ & 2.1 & $\mathrm{a}$ & 1.9 & $\mathrm{a}$ \\
\hline $\mathrm{Al}+\mathrm{H}\left(\mathrm{cmol}_{\mathrm{C}} \mathrm{cm}^{-3}\right)$ & 8.8 & $\mathrm{a}$ & 7.0 & $\mathrm{~b}$ & 7.1 & $\mathrm{~b}$ & 7.9 & $a b$ & 8.8 & $\mathrm{a}$ & 5.6 & $\mathrm{~b}$ \\
\hline CECpot $\left(\mathrm{cmol}_{\mathrm{C}} \mathrm{L}^{-1}\right)$ & 12.8 & $\mathrm{a}$ & 11.5 & $\mathrm{bc}$ & 11.1 & $\mathrm{~b}$ & 12.4 & $\mathrm{ac}$ & 12.6 & $\mathrm{a}$ & 10.7 & $\mathrm{~b}$ \\
\hline AlSpot (\% of CECpot) & 17.3 & $\mathrm{a}$ & 12.9 & $\mathrm{a}$ & 14.9 & $\mathrm{a}$ & 15.2 & $\mathrm{a}$ & 17.9 & $\mathrm{a}$ & 9.4 & $\mathrm{~b}$ \\
\hline BsSpot (\% of CECpot) & 32.7 & $\mathrm{a}$ & 40.3 & $\mathrm{a}$ & 36.6 & $\mathrm{a}$ & 37.2 & $\mathrm{a}$ & 30.8 & $\mathrm{a}$ & 48.3 & $\mathrm{~b}$ \\
\hline
\end{tabular}

A) Plots with different distance from the forest border (1: border; 3, 5, 7: grassland); B) Plots with different location in the study area (top and northern slope). Analyses A and B were conducted separately, with random permutations restricted within transect pairs in A. Values followed by identical letters do not significantly differ within A or B $(\mathrm{p}<0.05)$. 


\section{CONGRUENCE OF VEGETATION AND ENVIRONMENTAL DATA}

Total congruence with environmental data (soil parameters and aspect) was 0.19 for the full data set. Maximum congruency was reached with the variable aspect, $\mathrm{pH}$, content of clay, depth, and content of P (congruence coefficient: 0.30). Concerning only the grassland plots, congruence between vegetation data and the full environmental data set (soil variables and aspect) reached a value of 0.29 . Here, maximum congruence was reached with aspect, content of clay, aluminium content, depth and content of organic material, giving a correlation coefficient of 0.43 . Aspect alone led to a congruence coefficient of 0.36 for grassland plots and 0.21 when using all plots.

\section{DISCUSSION AND CONCLUSIONS}

The vegetation matrix of the studied grassland is formed by caespitose grasses, only three of which (E. muticus, A. flaccida, A. laevis) occur in more than $50 \%$ of the plots. Interstitial gaps between the grass tussocks are being populated by grassland shrubs and by a large number of herbaceous species, in their majority only sparsely distributed in the area and thus primarily contributing to the high diversity. The grassland vegetation on Morro Santana includes some relatively rare species: the Asteraceae Schlechtendalia luzulaefolia, possibly endemic for the granitic hills near Porto Alegre, Moritzia ciliata (Boraginaceae), endemic for Rio Grande do Sul, Butia capitata (Arecaceae), Waltheria douradinha (Sterculiaceae) and Parodia ottonis (Cactaceae), all listed in the red data book for Rio Grande do Sul (IBAMA, 2004). No exotic species were sampled in our study.

A study by Aguiar et al. (1986), mentioning 867 forest and grassland species for the granitic hills of the Porto Alegre region, gives an additional 140 grassland species and 20 species of the forest border for Morro Santana that had not been found in our study. The species list given by Mohr (unpubl.) for his study on Morro Santana contains another 24 species. Outside the plots, we collected an additional 15 species and found 30 more species in an evaluation of the soil seed bank of the grasslands on Morro Santana (unpubl.). Together with the data presented, this adds up to 430 completely identified species in a grassland area of approx. 220 ha.
Considering that all surveys present a large number of not completely identified species, we estimate the total number of species to be between 450 and 500. Thus, grassland vegetation on Morro Santana can be considered very species-rich compared to other vegetation types in the region, or to other grassland ecosystems worldwide. The total number of species in grasslands in the Porto Alegre region in general is more than twice as high as forests (Aguiar et al., 1986). Walker (2001) mentions the presence of 80 to 100 vascular species per ha in South African savannas and of 300 to 330 species for Brazilian Cerrado. Filgueiras et al. (1998) evaluated species composition of six different Cerrado areas in Central Brazil and found species numbers between 52 and 121 for the herbaceous layer (area sampled $50 \mathrm{~m}^{2}$ for each area). Numbers from Morro Santana seem to be at least in the same range as in these studies. Small-scale richness on Morro Santana was higher that that cited for Cerrado in Filgueiras (2002), where eight to 28 species were found per $1 \mathrm{~m}^{2}$, and similar to that of species-rich limestone meadows in Sweden, where Van Der Maarel \& Sykes (1993) found a maxima of around 33 species per $0.25 \mathrm{~m}^{2}$. Clearly, the comparison of species numbers between surveys is problematic due to different sampling methods, different homogeneity of the vegetation and the size of the studied area. Nonetheless, the data presented here indicates high species richness in comparison with other grasslands. The total number of grassland species in southern Brazil has been estimated to be around 3000 (Boldrini, 2002), thus lower than the one proposed for the Cerrado region (6000 vascular species) by Furley (1999). However, it should be remembered that Cerrado sensu latu comprises other physiognomic vegetation types besides campo sujo and campo limpo, the equivalent to grassland vegetation in southern Brazil, and shows a very diverse woody component that is lacking in Campos grassland. Furthermore, Cerrado (total area 2 million $\mathrm{km}^{2}$ ) covers a much larger area than South Brazilian Campos, therefore also including a higher variability in climatic and edaphic conditions (Furley, 1999) than the comparatively uniform campos region (MMA, 2000). This emphasizes species richness of the Campos vegetation as a whole and indicates that the South Brazilian humid subtropical grassland biome should be considered as a biodiversity hotspot, such as, for example, the 
Cerrado or the Mata Atlântica region (Myers et al., 2000). The necessity exists to conduct vegetation sampling with comparable methods in the whole region to obtain interpretable information on species distribution patterns and diversity on a larger scale, and to be able to compare Campos vegetation of southern Brazil to the Pampas in Argentina and Uruguay and to Cerrado vegetation in central Brazil.

When comparing the species composition of the (ungrazed) grassland studied in our study to that of other grasslands in Rio Grande do Sul, it becomes obvious that rhizomateous or stoloniferous grasses favored by cattle grazing, e.g. Axonopus affinis, Paspalum notatum or $P$. paucifolium, often forming a dense carpet in the lower strata of grazed grasslands (e.g., Boldrini \& Miotto, 1987), were of low importance on Morro Santana, both concerning total cover and species number. Concordingly, Boldrini \& Eggers (1996) stated a shift from rhizomateous and stoloniferous species to high tussock grasses in the absence of grazing. The strong presence of the woody component in our study when compared to grazed grassland (e.g., Boldrini, 1993) indicates that these species may be less tolerant to grazing than to fire, and that, on the other hand, diversity of growth forms may be higher in grasslands in close contact with forests, as is the case on Morro Santana, where grasslands are subject to invasion of woody species (Müller \& Forneck, 2004). In our study, plots situated close to the forest border showed a marked structural and compositional difference, caused by lower light availability and the significant litter layer. The number of herbaceous species adapted to these conditions, e.g. Oplismenus hirtellus or Peperomia pereskiaefolia, seems to be much lower, just as the herbaceous strata in subtropical forests only comprise relatively few species (Müller \& Waechter, 2001). Plots situated $10 \mathrm{~m}$ from the forest border, on the other hand, could clearly be considered as grassland plots, not differing from plots farther in the grassland. This indicates that the transitional zone between forest and grassland is very abrupt, most likely due to the frequent burning that burns all the grassland but stops at the border due to lack of flammable biomass. The forests themselves are too moist to burn (Pillar \& Quadros, 1997). Despite the abrupt border between forest and grassland, the proximity of the forest does increase the number of species and structural heterogeneity in the grassland due to the establishment of forest pioneer species and the presence of small shrubland patches, considered to be nuclei of forest expansion (Müller \& Forneck, 2004). Ecotones like the forest-grassland mosaic on Morro Santana show complex interactions between vegetation types and abiotic factors, such as soil properties or aspect and fire regime. Even though young individuals of forest species may not survive all fires and shrubland patches may not be stable under the present disturbance regime as well, they contribute to spatial and temporal heterogeneity, affecting species diversity and vegetation structure (Hopkins, 1992). This emphasizes that one vegetation type cannot be considered isolated from its surroundings and underlines the high biodiversity of vegetation mosaics, such as in the Porto Alegre region.

In our study, correlations of compositional data and environmental data seemed to indicate a rather strong influence mainly of aspect on species composition. Boldrini et al. (1998) linked differences between vegetation composition on the southern and northern slopes on Morro de Polícia, Porto Alegre, to higher solar radiation causing drier conditions on the northern slope. Focht \& Pillar (2003) found that soil moisture related to the topographic position was the most important factor explaining species composition in grazed grassland. While we did not have such a significant topographic gradient, nonetheless nearly all soil factors analysed differed significantly between the top and the northern slope of the hill, which are drier due to the lower depth, slope and aspect. Thus, grassland in these areas may burn more often and intensively and therefore suffer stronger erosion processes, with principally the latter changing soil properties. This may of course influence the composition of species in the long run. However, the significant presence of some species on only one side of the hill or in only some of the transects, as indicated by the separation of plots on the top and on the northern slope in the ordination diagram (Fig. 1b), may simply be a consequence of the heterogeneous species distribution revealed by our study; the low explanation of the ordination axes supports this hypothesis. According to Grubb (1986), most species in very species-rich communities are likely to have sparse distribution and "consistently low populations" (Rabinowitz, 
1981; cited in Grubb, 1986). In our case, few species were distributed throughout the entire study area. We suppose that the lack of stabilization of the species-area-curve does not stem from sampling insufficiency, but from the high proportion of rare species - the curve will never stabilize in such a species-rich system. Vegetation structure, at least when only considering the grassland matrix, was relatively homogeneous throughout the grasslands, but compositional differences increased with distance between compared plots. This clumped distribution of species makes causal explanations concerning the role of environmental factors much more difficult. Differences in composition might be related to abiotic factors, but also to dispersal limitation over space (Tilman, 1997; Turnbull et al., 2000) or stochastic fluctuation processes, which are thought to be of special importance in grasslands, where patch structure is not necessarily correlated with the composition of species (Glenn \& Collins, 1993).

The studied grassland is subject to frequent anthropogenic burning. Fire is an important factor in many grassland systems (e.g. Vogl, 1974; Bond \& Wilgen, 1996) and its central role in maintaining open, i.e. non-forest, vegetation under climatic conditions favorable for forest development is generally accepted (e.g. Sauer, 1950; Vogl, 1974; Hobbs \& Huenneke, 1992). As discussed, recurrent fires stabilize the forest-grassland mosaic on Morro Santana as well. The few studies conducted so far on the influence of fire on vegetation of grasslands in southern Brazil have shown that grassland vegetation will most likely recover quickly to its preburn state concerning the composition and cover of species, as the majority of species resprouts shortly after the fire (Eggers \& Porto, 1994; Quadros \& Pillar, 2001). While this remains to be studied in detail for our study area, we do suppose that the high fire frequency, at least partially, explains the high species richness found, as disturbance is generally considered to enhance species diversity in grassland communities (e.g. Denslow, 1985). This is mainly due to decreased competitive interactions of dominant species, which would become more important in the absence of disturbance, leading to the loss of weaker competitors (e.g. Crawley, 1997) and to increased possiblities for seedling recruitment in the post-fire environment. At any rate, regular disturbances such as fire and grazing seem to be the key-factors necessary for the maintenance of grassland vegetation under the present climatic conditions (Pillar \& Quadros, 1997), and thus for preservation of biodiversity in the region. Considering the fast conversion of South Brazilian natural grassland into Pinus plantations, mainly in the north-eastern Planalto region of Rio Grande do Sul, and into agricultural production area in large parts of the Campos region, research on biodiversity and conservation value of grasslands in southern Brazil and subsequent implementation of conservation measures are clearly necessary in order to impede irreversible losses in an extremely species-rich biome.

Acknowledgments - We would like to thank staff at the UFRGS Department of Botany, especially Ilsi Boldrini, for their help with the identification of collected plant material. Our thanks go to UFRGS security personnel for accompanying us in the field. G.O. received a PhD grant by the German National Academic Foundation, S.M. a CAPES PhD grant and V.P. CNPq support. The study was supported by the DFG (German Research Foundation) and by CAPES (Brazil) and DAAD (Germany) under Probral.

\section{REFERENCES}

ADELMANN, W. \& ZELLHUBER, A., 2004, Analysis of environmental conflicts in areas of urban expansion using scenario methods, pp. 60-64. In: M. L. Porto (ed.), "Workshop Proteção e manejo da vegetação natural da região de Porto Alegre com base em pesquisas de padrões e dînamica da vegetação", UFRGS, PPG Ecologia. Porto Alegre.

AGUIAR, L. W., MARTAU, L., SOARES, Z. F., BUENO, O. L., MARIATH, J. E. \& KLEIN, R. M., 1986, Estudo preliminar da flora e vegetação de morros graníticos da Região da Grande Porto Alegre, Rio Grande do Sul, Brasil. Iheringia, Ser. Bot., 34: 3-34.

BEHLING, H., PILLAR, V. D., ORLÓCI, L. \& BAUERMANN, S. G., 2004, Late Quaternary Araucaria forest, grassland (Campos), fire and climate dynamics, studied by high resolution pollen, charcoal and multivariate analysis of the Cambará do Sul core in southern Brazil. Palaeogeogr., Palaeocl., 203: 277-297.

BEHLING, H., PILLAR, V. D., MÜLLER, S. C. \& OVERBECK, G. E. in press: Late Holocene vegetation and fire dynamics of Morro Santana, Porto Alegre, and its implication for management and conservation in southern Brazil. Appl. Veg. Sci.

BILENCA, D. N. \& MIÑARRO, F. O., 2004, Áreas valiosas de pastizal em las pampas y campos de Argentina, Uruguay y sur de Brasil. Fundación Vida Silvestre Argentina, Buenos Aires.

BOLDRINI, I. B., 1993, Dinâmica de vegetação de uma pastagem natural sob diferentes níveis de oferta de forragem e tipos de solos, Depressão Central, RS. PhD 
thesis, Faculdade de Agronomia, UFRGS, Porto Alegre, $259 \mathrm{p}$.

BOLDRINI, I. B., 2002, Campos sulinos: caracterização e biodiversidade, pp. 95-97. In: E. d. L. Araújo, A. d. N. Noura, E. V. d. S. B. Sampaio, L. M. d. S. Gestinari \& J. d. M. T. Carneiro (eds.), Biodiversidade, conservação e uso sustentável da flora do Brasil, UFRPE, Recife.

BOLDRINI, I. B. \& EGGERS, L., 1996, Vegetação campestre do sul do Brasil: resposta e dinâmica de espécies à exclusão. Acta Bot. Bras., 10: 37-50.

BOLDRINI, I. B. \& MIOTTO, S. T. S., 1987, Levantatmento fitossociólogico de um campo limpo da estação experimental agronomica, UFRGS, Guaiba, RS - $1^{\text {a }}$. etapa. Acta Bot. Bras., 1: 49-56.

BOLDRINI, I. B., MIOTTO, S. T. S., LONGHI-WAGNER, H. M., PILLAR, V. D. \& MARZALL, K., 1998, Aspectos florísticos e ecológicos da vegetação campestre do Morro da Polícia, Porto Alegre, RS, Brasil. Acta Bot. Bras., 12: 89-100.

BOND, W. J. \& V. WILGEN, B. W., 1996, Fire and plants. Chapman \& Hall, London.

BUSElato, T. C. \& BUENO, O. L., 1981, Composição florística de dois campos localizados no Municipio de Montenegro, Rio Grande do Sul, Brasil. Iheringia, Ser. Bot., 26: 65-84.

CRAWLEY, M., 1997, Plant ecology. Blackwell. Oxford. 717p.

DENSLOW, J., 1985, Disturbance-mediated coexistence of species, pp. 307-323. In: S. T. A. Pickett \& P. White (eds.), The ecology of natural disturbance and patch dynamics, Academic Press, San Diego.

EGGERS, L. \& PORTO, M. L., 1994, Ação do fogo em uma comunidade campestre secundaria, analisada em bases fitossociológicas. Bol. Inst. Biociências UFRGS, 53: 1-88.

FILGUEIRAS, T. S., 2002, Herbaceous plant communites, pp. 121-139. In: P. S. Oliveira \& R. J. Marquis (eds.), The cerrados of Brazil: ecology and natural history of a neotropical savanna, Columbia University Press. New York.

FILGUEIRAS, T. S., FELFILI, J. M., DA SILVA, M. C. \& NOGUEIRA, P. E., 1998, Floristic and structural comparison of Cerrado (sensu stricto) vegetation in Central Brasil, pp. 633-648. In: F. Dallmeier \& J. A. Comiskey (eds.), Forest biodiversity in North, Central, and South America, and the Caribbean, Parthenon Publishing Group. New York.

FOCHT, T. \& PILLAR, V. D., 2003, Spatial patterns and relations with site factors in a campos grassland under grazing. Braz. J. Biol., 63: 423-436.

FURLEY, P. A., 1999, The nature and diversity of neotropical savanna vegetation with particular reference to the Brazilian cerrados. Glob. Ecol. Biogeo., 8: 223-241.

GIRARDI-DEIRO, A., GONÇALVES, J. O. M. \& GONZAGA, S. S., 1992, Campos naturais ocorrentes nos diferentes tipos de solo no município de Bagé, Rio Grande do Sul. 2: fisionomia e composição florística. Iheringia, Ser. Bot., 42: 55-79.

GLENN, S. M. \& COLLINS, S. L. 1993, Experimental analysis of patch dynamics in tallgrass prairie plant communities. $J$. Veg. Sci. 4: 157-162.
GRUBB, P. J. 1986, Problems posed by sparse and patchitly distributed species in species-rich plant communities, pp. 207-225. In: J. Diamond \& T. J. Case (eds.), Community ecology, Harper and Row, New York.

HOBBS, R. J. \& HUENNEKE, L. F., 1992, Disturbance, diversity, and invasion: implications for conservation. Cons. Biol., 6: 324-337.

HOPKINS, B. 1992, Ecological processes at the forest-savanna boundary, pp. 21-33. In: P. A. Furley, J. Proctor \& J. A. Ratter (eds.), Nature and dynamics of forest-savanna boundaries. Chapman \& Hall, London.

IBAMA, 2004, Espécies da flora ameaçadas de extinção do Rio Grande do Sul, URL: http://www.sema.rs.gov.br/sema/ html/pdf/especies-ameacadas.pdf (accessed 11 Jan. 2005).

IPNI (INTERNATION PLANT NAMEs INDEX), 2004, Published on the Internet http://www.ipni.org (accessed 13 May, 2005).

KLEIN, R. M., 1975, Southern Brazilian phytogeographic features and the probable influence of upper quaternary climatic changes in the floristic distribution. Bol. Paran. Geociências, 33: 67-88.

KREBS, C. J., 1998, Ecological Methodology. Benjamin/ Cummings, Menlo Park, 620p.

LONDO, G., 1976, The decimal scale for releves of permanent quadrats. Vegetatio, 33: 61-64.

MMA, 2000, Avaliação e ações prioritárias para a conservação da biodiversidade da Mata Atlântica e Campos Sulinos. Relatório técnico, Brasília, 581p.

MÜLLER, S. C. \& FORNECK, E. D., 2004, Forest-grassland mosaics in the hills of Porto Alegre: a study case of forest expansion patterns in Santana hill, Rio Grande do Sul, Brazil, pp. 29-37. In: M. L. Porto (ed.), "Workshop Proteção e manejo da vegetação natural da região de Porto Alegre com base em pesquisas de padrões e dînamica da vegetação", UFRGS, PPG Ecologia, Porto Alegre.

MÜLLER, S. C. \& WAECHTER, J. L., 2001, Estrutura sinusial dos componentes herbáceo e arbustivo de uma floresta costeria subtropical. Rev. Bras. Bot., 24: 395-406.

MYERS, N., MITTERMEIER, R. A., MITTERMEIER, C. G., FONSECA, G. A. B. D. \& KENT, J., 2000, Biodiversity hotspots for conservation priorities. Nature, 403: 853-858.

NABINGER, C. A., MORAES, A. D. \& MARASCHIN, G. E., 2000, Campos in southern Brazil, pp. 355-376. In: G. Lemaire, J. G. Hodgson, A. d. Moraes \& G. E. Maraschin (eds.), Grassland ecophysiology and grazing ecology, CABI Publishing, Wallingford.

NIMER, E., 1990, Clima, pp. 151-187. In: IBGE (eds.), Geografia do Brasil: Região Sul, IBGE, Rio de Janeiro.

OVERBECK, G. E., MÜlleR, S. C., PILlaR, V. P. \& PFADENHAUER, J. 2005: Small-scale dynamics after fire in South Brazilian humid subtropical grassland. J. Veg. Sci., 16: 655-664.

PILLAR, V. D., 1999, The bootstrapped ordination re-examined. J. Veg. Sci., 10: 895-905.

PILLAR, V. D., 2003, Dinâmica da expansão florestal em mosaicos de floresta e campos no sul do Brasil, pp. 209-216. In: V. Claudino-Sales (ed.), Ecossistemas brasileiros: manejo e conservação, Expressão, Fortaleza. 
PILLAR, V. D., 2004a, MULTIV: Multivariate Exploratory Analysis, Randomization Testing and Bootstrap Resampling. User's Guide v. 2.3.10. Departamento de Ecologia, UFRGS, Porto Alegre, RS, Brazil. URL: http:// ecoqua.ecologia.ufrgs.br

PILLAR, V. D., 2004b, SYNCSA, v. 2.2. Departamento de Ecologia, UFRGS, Porto Alegre, RS, Brazil. URL: http:// ecoqua.ecologia.ufrgs.br

PILLAR, V. D., JAQUES, A. V. A. \& BOLDRINI, I. B., 1992, Fatores de ambiente relacionados a variação da vegetação de um campo natural. Pesqu. Agropec. Bras., 27: 1089-1101.

PILlAR, V. D. \& ORLÓCI, L., 1993, Character-based community analysis: the theory and an application program. SPB Academic Publishing, The Hague, 270p.

PILLAR, V. D. \& ORLÓCI, L., 1996, On randomization testing in vegetation science: multifactor comparisons of relevé groups. J. Veg. Sci., 7: 585-592.

PILLAR, V. D. \& QUADROS, F. L. F., 1997, Grassland-forest boundaries in southern Brazil. Coenoses, 12: 119-126.

PODANI, J., 2000, Introduction to the exploration of multivariate biological data. Backhuys Publishers, Leiden, 407p.

QUADROS, F. L. F. \& PILLAR, V. D., 2001, Dinâmica vegetational em pastagem natural submetida tratamento de queima e pastejo. Ciência Rural, 31: 863-868.

RAMBO, B., 1954, Análise historica da flora de Porto Alegre. Sellowia, 6: 9-112.

RAMBO, B., 1956, A fisionomia do Rio Grande do Sul. Selbach, Porto Alegre, 472p.
RHEINHEIMER, D. D. S., SANTOS, J. C. P., FERNANDES, V. B. B., ALVARO, L. M. \& ALMEIDA, J. A., 2003, Modificações nos atributos químicos de solo sob campo nativo submetido à queima. Ciência Rural, 33: 49-55.

SAUER, C. O., 1950, Grassland climax, fire, and man. J. Range Manage., 3: 16-21.

STRECK, E. V., KÄMPF, N., DALMOLIN, R. S. D., KLAMT, E., NASCIMENTO, P. C. d. \& SCHNEIDER, P., 2002, Solos do Rio Grande do Sul. Editora da UFRGS, Porto Alegre, 107p.

TEDESCO, M. J., GIANELLO, C., BISSANI, C.A., BOHNEN, H. \& VOLKWEISS, S. J., 1995. Análises de solo, plantas e outros materiais, UFRGS, Porto Alegre, 174p.

TILMAN, D., 1997, Community invasibility, recruitment limitation, and grassland biodiversity. Ecology, 78: 81-92.

TURNBULL, L. A., CRAWLEY, M. \& REES, M., 2000, Are plant populations seed-limited? A review of seed sowing experiments. Oikos, 88: 225-238.

VAN DER MAAREL, E. \& SYKES, M. T., 1993, Small-scale plant species turnover in a limestone grassland: the carousel model and some comments on the niche concept. J. Veg. Sci., 4: 179-188.

VOGL, R.J., 1974, Effects of fire on grasslands, pp. 139-194. In: T. T. Kozlowski \& C. E. Ahlgren (eds.), Fire and ecosystems, Academic Press, New York.

WALKER, B., 2001, Tropical savanna, pp. 139-156. In: F. S. Chapin, O. E. Sala \& E. Huber-Sannwald (eds.), Global biodiversity in a changing environment, Springer, Berlin.

\section{APPENDIX 1}

Family, species name, biological form (see text), absolute frequency $\left(F_{s}\right)$, relative frequency $\left(R_{s}\right)$, relative cover $\left(R_{s}\right)$ and importance value $\left(\mathrm{IV}_{\mathrm{s}}\right)$ of the species found in grassland plots $(\mathrm{n}=36)$ of $0.75 \mathrm{~m}^{2}$ on Morro Santana, Porto Alegre, RS, Brazil. For grasses, basal architecture is indicated (c: caespitose, s: stoloniferous, r: rhizomateous, cr: caespitose or rhizomateous). Nomenclature according to IPNI (2004).

\begin{tabular}{|c|c|c|c|c|c|c|}
\hline Family & Species & $\begin{array}{l}\text { Biol. } \\
\text { form }\end{array}$ & $\begin{array}{l}\text { Fs } \\
(\%)\end{array}$ & $\begin{array}{l}\text { RFs } \\
(\%)\end{array}$ & $\begin{array}{l}\mathrm{RCs} \\
(\%)\end{array}$ & $\begin{array}{l}\text { IVs } \\
(\%)\end{array}$ \\
\hline Amaranthaceae & Pfaffia tuberosa (Moq. ex DC.) Hicken & herb & 61 & 1.80 & 0.84 & 2.65 \\
\hline Amaryllidaceae & Habranthus gracilifolius Herb. & geophyte & 11 & 0.33 & 0.05 & 0.38 \\
\hline Anacardiaceae & Schinus weinmanniaefolius Engl. & shrub & 11 & 0.33 & 0.65 & 0.98 \\
\hline \multirow[t]{6}{*}{ Apiaceae } & Eryngium ciliatum Cham. \& Schlecht. & herb & 8 & 0.25 & 0.07 & 0.31 \\
\hline & Eryngium elegans Cham. \& Schlecht. & herb & 3 & 0.08 & 0.09 & 0.18 \\
\hline & Eryngium horridum Malme & herb & 50 & 1.48 & 3.10 & 4.58 \\
\hline & Eryngium pristis Cham. \& Schlecht. & herb & 17 & 0.49 & 4.72 & 5.21 \\
\hline & $\begin{array}{l}\text { Eryngium sanguisorba Cham. \& } \\
\text { Schlecht. }\end{array}$ & herb & 44 & 1.31 & 0.87 & 2.18 \\
\hline & Hydrocotyle exigua (Urb.) Malme & herb & 50 & 1.48 & 0.52 & 2.00 \\
\hline \multirow[t]{5}{*}{ Asteraceae } & Acmella bellidioides (Sm.) R.K.Jansen & herb & 17 & 0.49 & 0.37 & 0.86 \\
\hline & Achyrocline satureioides Gard. & herb & 25 & 0.74 & 0.26 & 0.99 \\
\hline & Aspilia montevidensis (Spreng.) Kuntze & herb & 53 & 1.56 & 1.32 & 2.88 \\
\hline & Baccharis articulata Pers. & shrub & 3 & 0.08 & 0.04 & 0.12 \\
\hline & Baccharis cognata DC. & shrub & 53 & 1.56 & 2.65 & 4.20 \\
\hline
\end{tabular}




\begin{tabular}{|c|c|c|c|c|c|c|}
\hline \multicolumn{7}{|c|}{$\begin{array}{c}\text { APPENDIX } 1 \\
\text { Continued... }\end{array}$} \\
\hline Family & Species & $\begin{array}{l}\text { Biol. } \\
\text { form }\end{array}$ & $\begin{array}{l}\text { Fs } \\
(\%)\end{array}$ & $\begin{array}{l}\text { RFs } \\
(\%) \\
\end{array}$ & $\begin{array}{r}\mathrm{RCs} \\
(\%) \\
\end{array}$ & $\begin{array}{l}\text { IVs } \\
(\%)\end{array}$ \\
\hline & Baccharis dracunculifolia DC. & shrub & 8 & 0.25 & 0.21 & 0.45 \\
\hline & Baccharis leucopappa DC. & shrub & 28 & 0.82 & 0.24 & 1.06 \\
\hline & Baccharis ochracea Spreng. & shrub & 6 & 0.16 & 0.30 & 0.47 \\
\hline & Baccharis patens Baker & shrub & 14 & 0.41 & 2.68 & 3.09 \\
\hline & Baccharis sessiliflora Vahl & shrub & 25 & 0.74 & 0.52 & 1.26 \\
\hline & Baccharis trimera (Less.) DC. & shrub & 22 & 0.66 & 0.26 & 0.91 \\
\hline & Calea uniflora Krasch. & herb & 3 & 0.08 & 0.01 & 0.09 \\
\hline & Chaptalia integerrima (Vell.) Burkart & herb & 19 & 0.57 & 0.17 & 0.74 \\
\hline & Chaptalia runcinata Kunth & herb & 56 & 1.64 & 0.83 & 2.48 \\
\hline & Chaptalia sinuata Baker & herb & 25 & 0.74 & 0.31 & 1.05 \\
\hline & Conyza bonariensis (L.) Cronquist & herb & 3 & 0.08 & 0.01 & 0.09 \\
\hline & Conyza chilensis Spreng. & herb & 6 & 0.16 & 0.04 & 0.20 \\
\hline & Eupatorium ascendens Sch.Bip. ex Baker & herb & 6 & 0.16 & 0.04 & 0.20 \\
\hline & Eupatorium ivaefolium $\mathrm{L}$. & herb & 33 & 0.98 & 0.47 & 1.46 \\
\hline & Eupatorium lanigerum Hook. \& Arn. & herb & 3 & 0.08 & 0.02 & 0.10 \\
\hline & Eupatorium ligulaefolium Hook. \& Arn. & shrub & 50 & 1.48 & 0.93 & 2.41 \\
\hline & Eupatorium tweedianum Hook. \& Arn. & herb & 6 & 0.16 & 0.11 & 0.28 \\
\hline & Heterothalamus psiadioides Less. & shrub & 33 & 0.98 & 1.23 & 2.22 \\
\hline & Hieracium commersonii Monnier & herb & 11 & 0.33 & 0.13 & 0.46 \\
\hline & Hypochoeris sp. 1 & herb & 3 & 0.08 & 0.04 & 0.12 \\
\hline & Lucilia acutifolia Cass. & herb & 56 & 1.64 & 0.50 & 2.14 \\
\hline & Lucilia nitens Less. & herb & 14 & 0.41 & 0.17 & 0.58 \\
\hline & $\begin{array}{l}\text { Noticastrum gnaphalioides (Baker) } \\
\text { Cuatrec. }\end{array}$ & herb & 8 & 0.25 & 0.12 & 0.37 \\
\hline & Orthopappus angustifolius Gleason & herb & 31 & 0.90 & 0.46 & 1.37 \\
\hline & Porophyllum lanceolatum DC. & shrub & 56 & 1.64 & 0.37 & 2.01 \\
\hline & Pterocaulon alopecuroideum DC. & herb & 3 & 0.08 & 0.08 & 0.16 \\
\hline & Pterocaulon rugosum Malme & herb & 44 & 1.31 & 0.89 & 2.20 \\
\hline & Senecio heterotrichius DC. & herb & 14 & 0.41 & 0.10 & 0.51 \\
\hline & Stenachaenium riedelii Baker & herb & 6 & 0.16 & 0.09 & 0.26 \\
\hline & Stevia aristata D.Don ex Hook. \& Arn. & herb & 8 & 0.25 & 0.07 & 0.31 \\
\hline & Stevia cinerascens Sch.Bip. ex Baker & herb & 31 & 0.90 & 0.68 & 1.59 \\
\hline & Verbesina subcordata DC. & shrub & 8 & 0.25 & 0.12 & 0.37 \\
\hline & Vernonia flexuosa Sims & herb & 67 & 1.97 & 1.47 & 3.44 \\
\hline & Vernonia nudiflora Less. & shrub & 69 & 2.05 & 1.30 & 3.35 \\
\hline & Viguiera anchusaefolia (DC.) Bak. & herb & 6 & 0.16 & 0.08 & 0.24 \\
\hline & Asteraceae 1 & herb & 3 & 0.08 & 0.02 & 0.10 \\
\hline & Asteraceae 2 & herb & 3 & 0.08 & 0.01 & 0.09 \\
\hline Bromeliaceae & Dyckia leptostachya Baker & herb & 3 & 0.08 & 0.57 & 0.65 \\
\hline Cactaceae & Parodia ottonis (Lehm.) N.P.Taylor & cactus & 3 & 0.08 & 0.11 & 0.20 \\
\hline Campanulaceae & Wahlenbergia linarioides DC. & herb & 3 & 0.08 & 0.01 & 0.09 \\
\hline Cistaceae & Halimium brasiliense Gross. & herb & 17 & 0.49 & 0.10 & 0.60 \\
\hline Commelinaceae & Commelina erecta $\mathrm{L}$. & geophyte & 14 & 0.41 & 0.09 & 0.50 \\
\hline Convolvulaceae & Convolvulus crenatus Vahl & liana & 3 & 0.08 & 0.09 & 0.18 \\
\hline
\end{tabular}




\begin{tabular}{|c|c|c|c|c|c|c|}
\hline \multicolumn{7}{|c|}{$\begin{array}{l}\text { APPENDIX } 1 \\
\text { Continued... }\end{array}$} \\
\hline Family & Species & $\begin{array}{l}\text { Biol. } \\
\text { form }\end{array}$ & $\begin{array}{l}\text { Fs } \\
(\%)\end{array}$ & $\begin{array}{l}\text { RFs } \\
(\%)\end{array}$ & $\begin{array}{l}\mathrm{RCs} \\
(\%)\end{array}$ & $\begin{array}{l}\text { IVs } \\
(\%)\end{array}$ \\
\hline & Dichondra sericea $\mathrm{Sw}$. & liana & 22 & 0.66 & 0.16 & 0.82 \\
\hline & Evolvulus sericeus $\mathrm{Sw}$. & herb & 64 & 1.89 & 0.56 & 2.45 \\
\hline \multirow[t]{12}{*}{ Cyperaceae } & Bulbostylis closii Barros & Cyp. & 11 & 0.33 & 0.08 & 0.40 \\
\hline & $\begin{array}{l}\text { Bulbostylis juncoides (Vahl) Kük. ex } \\
\text { Osten }\end{array}$ & Cyp. & 42 & 1.23 & 0.29 & 1.52 \\
\hline & Bulbostylis sphaerocephalus C.B.Clarke & Cyp. & 11 & 0.33 & 0.18 & 0.51 \\
\hline & Bulbostyles sp. 1 & Cyp. & 11 & 0.33 & 0.09 & 0.41 \\
\hline & Carex phalaroides Kunth & Cyp. & 6 & 0.16 & 0.03 & 0.19 \\
\hline & Cyperus aggregatus Endl. & Cyp. & 14 & 0.41 & 0.08 & 0.49 \\
\hline & Cyperus lanceolatus Poir. & Cyp. & 6 & 0.16 & 0.03 & 0.19 \\
\hline & Rhynchospora globularis Small & Cyp. & 92 & 2.71 & 1.58 & 4.29 \\
\hline & Rhynchospora setigera Boeck & Cyp. & 19 & 0.57 & 0.09 & 0.67 \\
\hline & Scleria sellowiana Kunth & Cyp. & 36 & 1.07 & 0.28 & 1.35 \\
\hline & Scleria sp. 1 & Cyp. & 3 & 0.08 & 0.02 & 0.10 \\
\hline & Cyperaceae 1 & Cyp. & 3 & 0.08 & 0.02 & 0.10 \\
\hline Ebenaceae & Diospyros inconstans Jacq. & tree & 3 & 0.08 & 0.01 & 0.09 \\
\hline Erythroxylaceae & Erythroxylum argentinum O.E. Schulz & tree & 3 & 0.08 & 0.02 & 0.10 \\
\hline \multirow[t]{6}{*}{ Euphorbiaceae } & Croton cf. nitrariaefolium Baill. & shrub & 56 & 1.64 & 1.07 & 2.71 \\
\hline & Croton thermarum Müll.Arg. & shrub & 11 & 0.33 & 0.17 & 0.50 \\
\hline & $\begin{array}{l}\text { Euphorbia selloi (Klotzsch \& Garcke) } \\
\text { Boiss. in DC. }\end{array}$ & herb & 44 & 1.31 & 0.30 & 1.62 \\
\hline & Tragia emrichii Herter & herb & 3 & 0.08 & 0.02 & 0.10 \\
\hline & Euphorbiaceae 1 & herb & 3 & 0.08 & 0.02 & 0.10 \\
\hline & Euphrobiaceae 2 & herb & 3 & 0.08 & 0.01 & 0.09 \\
\hline \multirow[t]{16}{*}{ Fabaceae } & $\begin{array}{l}\text { Aeschynomene elegans Cham. \& } \\
\text { Schlecht. }\end{array}$ & herb & 22 & 0.66 & 0.17 & 0.83 \\
\hline & Centrosema virginianum Benth. & herb & 17 & 0.49 & 0.29 & 0.79 \\
\hline & Chamaecrista nictitans Moench & shrub & 8 & 0.25 & 0.19 & 0.44 \\
\hline & Clitoria nana Benth. & herb & 33 & 0.98 & 0.31 & 1.30 \\
\hline & Collaea stenophylla Benth. & shrub & 3 & 0.08 & 0.32 & 0.40 \\
\hline & Crotalaria tweediana Benth. & herb & 11 & 0.33 & 0.08 & 0.40 \\
\hline & Desmanthus tatuhyensis Hoehne & shrub & 50 & 1.48 & 0.46 & 1.94 \\
\hline & Desmodium affine Schltdl. & herb & 3 & 0.08 & 0.06 & 0.14 \\
\hline & Desmodium incanum DC. & herb & 8 & 0.25 & 0.20 & 0.45 \\
\hline & Galactia gracillima Benth. & liana & 6 & 0.16 & 0.02 & 0.18 \\
\hline & Galactia marginalis Benth. & herb & 25 & 0.74 & 0.23 & 0.97 \\
\hline & Macroptilium prostratum Urb. & herb & 25 & 0.74 & 0.25 & 0.98 \\
\hline & Mimosa parvipinna Benth. in Hook & shrub & 3 & 0.08 & 0.03 & 0.11 \\
\hline & Rhynchosia diversifolia Micheli & herb & 11 & 0.33 & 0.09 & 0.42 \\
\hline & Stylosanthes montevidensis Vogel & herb & 14 & 0.41 & 0.11 & 0.52 \\
\hline & Zornia sericea Moric. & herb & 6 & 0.16 & 0.04 & 0.20 \\
\hline \multirow[t]{3}{*}{ Iridaceae } & Cypella coelestis (Lehm.) Diels & geophyte & 11 & 0.33 & 0.05 & 0.38 \\
\hline & Herbertia pulchella Sweet & geophyte & 6 & 0.16 & 0.05 & 0.21 \\
\hline & Sisyrinchium macrocephalum Graham & herb & 17 & 0.49 & 0.17 & 0.66 \\
\hline
\end{tabular}




\begin{tabular}{|c|c|c|c|c|c|c|}
\hline \multicolumn{7}{|c|}{$\begin{array}{c}\text { APPENDIX } 1 \\
\text { Continued... }\end{array}$} \\
\hline Family & Species & $\begin{array}{l}\text { Biol. } \\
\text { form }\end{array}$ & $\begin{array}{l}\text { Fs } \\
(\%)\end{array}$ & $\begin{array}{l}\text { RFs } \\
(\%)\end{array}$ & $\begin{array}{l}\text { RCs } \\
(\%)\end{array}$ & $\begin{array}{l}\text { IVs } \\
(\%)\end{array}$ \\
\hline & Sisyrinchium scariosum I.M.Johnst. & herb & 11 & 0.33 & 0.05 & 0.38 \\
\hline & Sisyrinchium vaginatum Spreng. & herb & 14 & 0.41 & 0.19 & 0.60 \\
\hline \multirow[t]{3}{*}{ Lamiaceae } & Glechon squarrosa Benth. & herb & 17 & 0.49 & 0.30 & 0.80 \\
\hline & Hyptis stricta Benth. & herb & 3 & 0.08 & 0.04 & 0.12 \\
\hline & Salvia procurrens Benth. & herb & 11 & 0.33 & 2.58 & 2.91 \\
\hline Linaceae & $\begin{array}{l}\text { Cliococca selaginoides (Lam.) } \\
\text { C.M.Rogers \& Mild. }\end{array}$ & herb & 3 & 0.08 & 0.02 & 0.10 \\
\hline Lythraceae & Cuphea glutinosa Cham. \& Schlecht. & herb & 6 & 0.16 & 0.03 & 0.19 \\
\hline Malpighiaceae & Janusia cf. guaranitica A.Juss. & liana & 3 & 0.08 & 0.02 & 0.10 \\
\hline \multirow[t]{4}{*}{ Malvaceae } & $\begin{array}{l}\text { Krapovickasia urticifolia (A. St.-Hil.) } \\
\text { Fryxell }\end{array}$ & herb & 3 & 0.08 & 0.04 & 0.12 \\
\hline & Pavonia hastata Cav. & herb & 11 & 0.33 & 0.10 & 0.43 \\
\hline & Sida rhombifolia L. & herb & 6 & 0.16 & 0.06 & 0.22 \\
\hline & Wissadula glechomatifolia R.E.Fr. & herb & 17 & 0.49 & 0.31 & 0.81 \\
\hline Melastomatacea & Tibouchina gracilis (Bonpl.) Cogn. & herb & 42 & 1.23 & 0.83 & 2.06 \\
\hline Myrsinaceae & Myrsine umbellata Mart. & tree & 6 & 0.16 & 0.04 & 0.20 \\
\hline \multirow[t]{2}{*}{ Myrtaceae } & Campomanesia aurea O.Berg & shrub & 3 & 0.08 & 0.04 & 0.12 \\
\hline & Myrcia palustris DC. & tree & 3 & 0.08 & 0.23 & 0.31 \\
\hline Orchidaceae & $\begin{array}{l}\text { Stenorrhynchus arechavaletsmii Barb. } \\
\text { Rodr. }\end{array}$ & herb & 3 & 0.08 & 0.02 & 0.10 \\
\hline \multirow[t]{2}{*}{ Oxalidaceae } & Oxalis brasiliensis Lodd. & herb & 11 & 0.33 & 0.07 & 0.39 \\
\hline & Oxalis conorrhiza Jacq. & herb & 19 & 0.57 & 0.11 & 0.69 \\
\hline \multirow[t]{20}{*}{ Poaceae } & Andropogon lateralis Nees & grass (c) & 33 & 0.98 & 3.65 & 4.64 \\
\hline & Andropogon leucostachyus H. B. \& K. & grass $(\mathrm{c})$ & 25 & 0.74 & 1.52 & 2.26 \\
\hline & Andropogon selloanus (Hack.) Hack. & grass (c) & 31 & 0.90 & 1.06 & 1.96 \\
\hline & Andropogon ternatus Nees & grass (c) & 6 & 0.16 & 0.22 & 0.38 \\
\hline & Aristida circinalis Lindm. & grass (c) & 17 & 0.49 & 1.95 & 2.45 \\
\hline & Aristida condylifolia Caro & grass (c) & 6 & 0.16 & 0.06 & 0.22 \\
\hline & Aristida filifolia (Arechav.) Herter & grass (c) & 25 & 0.74 & 1.50 & 2.24 \\
\hline & Aristida flaccida Trin. \& Rupr. & grass $(\mathrm{c})$ & 58 & 1.72 & 5.75 & 7.47 \\
\hline & Aristida laevis Kunth & grass $(\mathrm{c})$ & 58 & 1.72 & 4.35 & 6.08 \\
\hline & Aristida venustula Arechav. & grass (c) & 6 & 0.16 & 0.02 & 0.18 \\
\hline & Axonopus argentinus Parodi & grass $(\mathrm{s})$ & 17 & 0.49 & 0.52 & 1.01 \\
\hline & $\begin{array}{l}\text { Axonopus suffultus (Mikan ex Trin.) } \\
\text { Parodi }\end{array}$ & grass $(\mathrm{c})$ & 17 & 0.49 & 1.92 & 2.41 \\
\hline & Axponopus sp. 1 & grass $(\mathrm{s})$ & 33 & 0.98 & 2.11 & 3.10 \\
\hline & Briza calotheca (Trin.) Hack & grass $(\mathrm{c})$ & 3 & 0.08 & 0.02 & 0.10 \\
\hline & Briza subaristata Lam. & grass (c) & 17 & 0.49 & 0.13 & 0.62 \\
\hline & Briza uniolae Nees ex Steud. & grass (c) & 17 & 0.49 & 0.18 & 0.67 \\
\hline & Briza sp. 1 & grass (c) & 11 & 0.33 & 0.06 & 0.39 \\
\hline & $\begin{array}{l}\text { Danthonia montevidensis Hackel \& } \\
\text { Arech. }\end{array}$ & grass (c) & 28 & 0.82 & 0.86 & 1.68 \\
\hline & Danthonia secundiflora J.Presl \& C.Presl & grass $(\mathrm{c})$ & 3 & 0.08 & 0.04 & 0.12 \\
\hline & $\begin{array}{l}\text { Dichanthelium sabulorum (Lam.) Gould } \\
\text { \& C.A.Clark }\end{array}$ & grass (r) & 56 & 1.64 & 1.00 & 2.64 \\
\hline
\end{tabular}


APPENDIX 1

Continued...

\begin{tabular}{|c|c|c|c|c|c|c|}
\hline Family & Species & $\begin{array}{l}\text { Biol. } \\
\text { form }\end{array}$ & $\begin{array}{l}\text { Fs } \\
(\%)\end{array}$ & $\begin{array}{l}\text { RFs } \\
(\%)\end{array}$ & $\begin{array}{l}\text { RCs } \\
(\%)\end{array}$ & $\begin{array}{l}\text { IVs } \\
(\%)\end{array}$ \\
\hline & Elionurus muticus (Spreng.) Kuntze & $\operatorname{grass}(\mathrm{c})$ & 61 & 1.80 & 7.60 & 9.41 \\
\hline & Eragrostis polytricha Nees & grass (c) & 17 & 0.49 & 0.21 & 0.70 \\
\hline & Leptocoryphium lanatum Nees & grass $(\mathrm{c})$ & 33 & 0.98 & 3.56 & 4.54 \\
\hline & Melica brasiliana Ard. & grass (r) & 3 & 0.08 & 0.02 & 0.10 \\
\hline & Panicum peladoense Henrard & grass $(\mathrm{c})$ & 6 & 0.16 & 0.02 & 0.18 \\
\hline & Paspalum plicatulum Michx. & grass $(\mathrm{c})$ & 25 & 0.74 & 0.35 & 1.09 \\
\hline & $\begin{array}{l}\text { Piptochaetium montevidense (Spreng.) } \\
\text { Parodi }\end{array}$ & grass $(\mathrm{c})$ & 42 & 1.23 & 1.17 & 2.40 \\
\hline & Saccharum asperum Steud & grass $(c)$ & 8 & 0.25 & 0.57 & 0.82 \\
\hline & $\begin{array}{l}\text { Schizachyrium microstachyum (Ham.) } \\
\text { Roseng., B.R.Arill. \& Izag. }\end{array}$ & grass $(c)$ & 28 & 0.82 & 1.14 & 1.96 \\
\hline & Schizachyrium spicatum (Spreng.) Herter & grass (c) & 6 & 0.16 & 0.04 & 0.20 \\
\hline & Schizachyrium tenerum Nees & grass $(\mathrm{c})$ & 36 & 1.07 & 3.22 & 4.29 \\
\hline & Setaria parviflora (Poiret) M.Kerguélen & $\begin{array}{l}\text { grass } \\
(\mathrm{cr})\end{array}$ & 33 & 0.98 & 0.52 & 1.51 \\
\hline & Setaria vaginata Spreng. & $\begin{array}{l}\text { grass } \\
(\mathrm{cr})\end{array}$ & 25 & 0.74 & 1.42 & 2.16 \\
\hline & Sporobolus multinodis Hackel & grass $(\mathrm{c})$ & 3 & 0.08 & 0.04 & 0.12 \\
\hline & Stipa filiculmis Delile & grass $(\mathrm{c})$ & 19 & 0.57 & 0.81 & 1.38 \\
\hline & Stipa filifolia Nees & grass $(\mathrm{c})$ & 14 & 0.41 & 0.69 & 1.10 \\
\hline & Stipa tenuiculmis Hackel & grass (c) & 11 & 0.33 & 0.08 & 0.40 \\
\hline & Trachypogon montufari Nees & grass $(\mathrm{c})$ & 25 & 0.74 & 2.74 & 3.48 \\
\hline & Poaceae 1 & $\operatorname{grass}(\mathrm{c})$ & 3 & 0.08 & 0.01 & 0.09 \\
\hline & Poaceae 2 & grass $(\mathrm{c})$ & 3 & 0.08 & 0.01 & 0.09 \\
\hline & Poaceae 3 & grass $(\mathrm{c})$ & 3 & 0.08 & 0.02 & 0.10 \\
\hline & Poaceae 4 & grass (c) & 3 & 0.08 & 0.04 & 0.12 \\
\hline & Poaceae 5 & grass (c) & 3 & 0.08 & 0.05 & 0.13 \\
\hline & Poaceae 6 & grass $(\mathrm{c})$ & 3 & 0.08 & 0.02 & 0.10 \\
\hline & Poaceae/trib. Andropogoneae 1 & grass $(\mathrm{c})$ & 3 & 0.08 & 0.02 & 0.10 \\
\hline & Poaceae/trib. Andropogoneae 2 & grass $(\mathrm{c})$ & 3 & 0.08 & 0.01 & 0.09 \\
\hline & Poaceae/trib. Andropogoneae 3 & grass (c) & 3 & 0.08 & 0.02 & 0.10 \\
\hline & Poaceae/trib. Andropogoneae 4 & $\operatorname{grass}(\mathrm{c})$ & 3 & 0.08 & 0.02 & 0.10 \\
\hline Polygalaceea & Monnina oblongifolia Arechav. & shrub & 17 & 0.49 & 0.23 & 0.72 \\
\hline \multirow[t]{10}{*}{ Rubiaceae } & Borreria capitata DC. & herb & 11 & 0.33 & 0.16 & 0.49 \\
\hline & Borreria fastigiata K.Schum. & herb & 42 & 1.23 & 0.68 & 1.91 \\
\hline & Borreria verticillata G.Mey. & herb & 6 & 0.16 & 0.06 & 0.22 \\
\hline & Chiococca alba Hitchc. & liana & 8 & 0.25 & 0.07 & 0.31 \\
\hline & Diodia apiculata K.Schum. & herb & 14 & 0.41 & 0.13 & 0.54 \\
\hline & Galium uruguayense Bacigalupo & herb & 22 & 0.66 & 0.11 & 0.77 \\
\hline & Relbunium hirtum K.Schum. & herb & 39 & 1.15 & 0.35 & 1.50 \\
\hline & Richardia grandiflora Steud. & herb & 50 & 1.48 & 0.83 & 2.31 \\
\hline & Richardia humistrata Steud. & herb & 3 & 0.08 & 0.02 & 0.10 \\
\hline & Rubiaceae sp. 1 & herb & 3 & 0.08 & 0.01 & 0.09 \\
\hline Scrophulariaceae & Angelonia integerrima Spreng. & herb & 3 & 0.08 & 0.08 & 0.16 \\
\hline
\end{tabular}




\begin{tabular}{|c|c|c|c|c|c|c|}
\hline \multicolumn{7}{|c|}{$\begin{array}{l}\text { APPENDIX } 1 \\
\text { Continued... }\end{array}$} \\
\hline Family & Species & $\begin{array}{l}\text { Biol. } \\
\text { form }\end{array}$ & $\begin{array}{l}\text { Fs } \\
(\%)\end{array}$ & $\begin{array}{l}\text { RFs } \\
(\%)\end{array}$ & $\begin{array}{l}\mathrm{RCs} \\
(\%)\end{array}$ & $\begin{array}{l}\text { IVs } \\
(\%)\end{array}$ \\
\hline & Gerardia communis Cham. \& Schlecht. & herb & 11 & 0.33 & 0.06 & 0.39 \\
\hline & $\begin{array}{l}\text { Mecardonia herniarioides (Cham.) } \\
\text { Pennell }\end{array}$ & herb & 3 & 0.08 & 0.02 & 0.10 \\
\hline Smilacaceae & Smilax campestris Griseb. & liana & 6 & 0.16 & 0.05 & 0.21 \\
\hline \multirow[t]{2}{*}{ Solanaceae } & $\begin{array}{l}\text { Petunia integrifolia (Hook.) Schinz \& } \\
\text { Thell. }\end{array}$ & herb & 8 & 0.25 & 0.07 & 0.31 \\
\hline & Petunia ovalifolia Miers & herb & 3 & 0.08 & 0.01 & 0.09 \\
\hline Sterculariaceae & Waltheria douradinha A. St.Hil. & herb & 11 & 0.33 & 0.09 & 0.41 \\
\hline Symplocaceae & Symplocos uniflora Benth. & tree & 3 & 0.08 & 0.04 & 0.12 \\
\hline \multirow[t]{2}{*}{ Turneraceae } & Turnera selloi Arechav. & herb & 14 & 0.41 & 0.09 & 0.50 \\
\hline & Turnera sidoides $\mathrm{L}$. & herb & 3 & 0.08 & 0.04 & 0.12 \\
\hline \multirow[t]{4}{*}{ Verbenaceae } & $\begin{array}{l}\text { Glandularia megapotamica (Spreng.) } \\
\text { Cabrera \& Dawson }\end{array}$ & herb & 3 & 0.08 & 0.02 & 0.10 \\
\hline & Lantana montevidensis (Spreng.) Briq. & shrub & 17 & 0.49 & 0.37 & 0.86 \\
\hline & Verbena ephedroides Cham. & herb & 11 & 0.33 & 0.04 & 0.37 \\
\hline & Verbena pseudojuncea Gay & herb & 8 & 0.25 & 0.06 & 0.30 \\
\hline Vitaceae & Cissus striata Ruíz \& Pav. & liana & 3 & 0.08 & 0.01 & 0.09 \\
\hline \multirow[t]{7}{*}{ Unidentified } & Sp. 1 & herb & 3 & 0.08 & 0.03 & 0.11 \\
\hline & Sp. 2 & herb & 3 & 0.08 & 0.01 & 0.09 \\
\hline & Sp. 3 & herb & 3 & 0.08 & 0.01 & 0.09 \\
\hline & Sp. 4 & herb & 3 & 0.08 & 0.01 & 0.09 \\
\hline & Sp. 5 & herb & 3 & 0.08 & 0.01 & 0.09 \\
\hline & Sp. 6 & herb & 3 & 0.08 & 0.01 & 0.09 \\
\hline & Sp. 7 & herb & 3 & 0.08 & 0.01 & 0.09 \\
\hline
\end{tabular}

APPENDIX 2

Species found in grassland plots at the forest-grassland border on Morro Santana, Porto Alegre, RS, Brazil. Given are family, species name, biological form (see text), with indication of basal architecture for grasses (see Appendix 1), and frequency $(F)$ in border plots $(n=12)$. Only species found exclusively in the border plots, i.e. species not listed in Appendix 1 are given. Nomenclature according to IPNI (2004).

\begin{tabular}{|l|l|l|c|}
\hline \multicolumn{1}{|c|}{ Family } & \multicolumn{1}{|c|}{ Species } & Biol. Form & F (\%) \\
\hline \multirow{2}{*}{ Acanthaceae } & Justicia brasiliana Roth & shrub & 8.3 \\
\cline { 2 - 4 } & Stenandrium Nees sp. & herb & 8.3 \\
\hline Apocynaceae & Forsteronia glabrescens Müll.Arg. & liana & 8.3 \\
\hline Aspidiaceae & Rumohra adiantiformis (G.Forst.) Ching & herb. fern & 16.7 \\
\hline \multirow{3}{*}{ Asteraceae } & Baccharis rufescens Spreng & shrub & 8.3 \\
\cline { 2 - 4 } & Calea serrata Less. & liana & 66.7 \\
\cline { 2 - 4 } & Eupatorium intermedium DC. & shrub & 8.3 \\
\cline { 2 - 4 } & Asteraceae 3 & herb & 8.3 \\
\hline \multirow{3}{*}{ Bignoniaceae } & Dolichandra cynanchoides Cham & woody liana & 8.3 \\
\cline { 2 - 4 } & Macfadyena unguis-cati (L.) A.H.Gentry & woody liana & 8.3 \\
\hline Boragniaceae & Moritzia ciliata DC. & herb & 8.3 \\
\hline Caryophylaceae & Spergularia grandis Cambess. & herb & 8.3 \\
\hline Convolvulaceae & Ipomoea nitida Griseb. & herb. liana & 8.3 \\
\hline Cyperaceae & Cyperus incomtus Kunth & Cyperaceae & 8.3 \\
\hline
\end{tabular}


APPENDIX 2

Continued...

\begin{tabular}{|c|c|c|c|}
\hline Dioscoreaceae & Dioscorea multiflora Mart. ex Griseb. & liana & 33.3 \\
\hline Ericaceae & Leucothoe eucalyptoides DC. & tree & 8.3 \\
\hline Euphorbiaceae & Sebastiania brasiliensis Spreng. & tree & 8.3 \\
\hline Liliaceae & Nothoscordum bonariense Beauverd & geophyte & 8.3 \\
\hline Myrsinaceae & Myrsine coriacea $\mathrm{R} . \mathrm{Br}$ & tree & 16.7 \\
\hline Myrtaceae & Blepharocalyx salicifolius O.Berg & tree & 8.3 \\
\hline Piperaceae & Peperomia pereskiaefolia H.B.\& K. & herb & 25.0 \\
\hline \multirow[t]{5}{*}{ Poaceae } & Calamagrostis viridiflavescens Steud. & grass $(\mathrm{r})$ & 41.7 \\
\hline & Oplismenus hirtellus (L.) P.Beauv. & grass (s) & 33.3 \\
\hline & Panicum ovuliferum Trin. & grass (s) & 25.0 \\
\hline & Paspalum mandiocanum Trin. & grass $(\mathrm{c})$ & 8.3 \\
\hline & Paspalum sp. 1 & grass $(\mathrm{c})$ & 16.7 \\
\hline \multirow[t]{3}{*}{ Rubiaceae } & Diodia cymosa Cham. & herb & 16.7 \\
\hline & Guettarda uruguensis Cham. \& Schlecht. & tree & 8.3 \\
\hline & Psychotria carthagenensis Jacq. & tree & 16.7 \\
\hline \multirow[t]{2}{*}{ Sapindaceae } & Cupania vernalis Cambess. & tree & 8.3 \\
\hline & Dodonaea viscosa Jacq. & tree & 25.0 \\
\hline Solanaceae & Cestrum strigillatum Ruiz \& Pav. & shrub & 8.3 \\
\hline Styracacae & Styrax leprosum Hook. et Arn. & tree & 8.3 \\
\hline Symplocaceae & Symplocos tetandra Mart. & tree & 8.3 \\
\hline
\end{tabular}

